\title{
SISTEM PENDIDIKAN SATU PIPA MA'HAD AL-ZAYTUN INDRAMAYU
}

\author{
Roni Tabroni \\ STKIP Pangeran Dharma Kusuma Segeran Indramayu, Jawa Barat, Indonesia \\ tabroni2506@gmail.com
}

\begin{abstract}
ONE PIPE EDUCATION SYSTEM OF MA'HAD AL-ZAYTUN INDRAMAYU. Ma'had Al-Zaytun Indramayu is one of pesantren or Islamic boarding schools that tries to integrate modernity and Islamic values. Innovation and modernization at Ma'had Al-Zaytun are realized in an education system with uninterrupted formal education implementation. It is known as One-Pipe Education System. This study used a case study method at Ma'had Al-Zaytun to analyze in depth about modernity and the religious sciences embodied in one pipe education system combined with the theory of social movement to see the leadership, ideology and ways of mobilizing their santri. It is also to see how Sheikh of Ma'had frames Islamic teachings combined with modernity in attracting sympathy and community participation. The results show that one pipe education system in Ma'had Al-Zaytun Indramayu is proved that they make santri to be modern and qualified in intelectual. It also instills national values, peace and tolerance. All of them will lead to the realization of santri as true Moslems.
\end{abstract}

Keywords: Ma'had Al-Zaytun, One Pipe Education System, National values, Peace, Tolerance.

\begin{abstract}
Abstrak
Ma'had Al-Zaytun Indramayu adalah salah satu pesantren yang berusaha melakukan integrasi antara modernitas dan nilai-nilaiagama
\end{abstract}


Islam. Inovasi dan modernisasi di Ma'had Al-Zaytun kemudian terwujud dalam suatu sistem pendidikan yang tidak terputus dalam pelaksanaan pendidikan formalnya yang kemudian dikenal denganSistem Pendidikan Satu Pipa. Penelitian ini menggunakan metode studi kasus di pesantren Ma'had Al-Zaytun untuk menganalisis secara mendalam pertemuan antara modernitas dan ilmu-ilmu agama yang berwujud dalam sistem pendidikan satu pipadipadukan dengan teori gerakan sosial untuk melihat kepemimpinan, ideologi dan cara mobilisasi para santrinya. Selain itu juga untuk melihat bagaimana sang Syekh Ma'had membingkai ajaran-ajaran Islam yang dipadukan dengan modernitas dalam menarik simpati dan partisipasi masyarakat. Hasil penelitian menunjukkan bahwa sistem pendidikan satu pipa terbukti bukan hanya membawa santri lebih bisa bersikap modern dan menjadi intelektual yang mumpuni, tetapi juga menanamkan nilai-nilai kebangsaan, perdamaian dan toleransi. Semua itu akan bermuara pada terwujudnya santri menjadi muslim kaffah.

Kata kunci: Ma'had Al-Zaytun, Sistem Pendidikan Satu Pipa, Nilainilai Kebangsaan, Perdamaian, Toleransi.

\section{A. Pendahuluan}

Banyak nilai-nilai penting yang bisa diambil dari sebuah pesantren. Nilai-nilai ini salah satunya muncul dari fungsi pesantren sebagai institusi pendidikan yang menjadikan Islam sebagai landasan dan asasnya. Nilai-nilai Islam ini secara otomatis kemudian menjadi nilai-nilai yang akan selalu diajarkan dan hidup di pesantren. Contohnya adalah sifat keikhlasan dan ketulusan yang dapat dilihat dari bagaimana santri menjalankan semua perintah kiai dengan penuh kerelaan. Berdasarkan hal tersebut, Mochtar Buchori memposisikan pesantren sebagai bagian dari struktur internal pendidikan Islam di Indonesia yang diselenggarakan secara tradisional dan menjadikan Islam sebagai cara hidup (Buchori, 1989: 189). Senada dengan hal tersebut, Zamaksyarie Dhofier berpendapat bahwa pesantren adalah lembaga pendidikan tradisional Islam yang berfungsi untuk mempelajari, memahami, menghayati, dan mengamalkan ajaran Islam dengan menekankan pentingnya moral keagamaan sebagai pedoman perilaku sehari-hari (Dhofier, 1982: 3). Dalam perkembangan gerakan Islam di Jawa, pesantren juga berperan sebagai lembaga pendidikan yang melakukan pemurnian ajaran dan praktik kegamaan dengan 
cara menggabungkan syariat dan tarekat. Gerakan ini di satu sisi melakukan perubahan ke arah ketaatan dalam menjalankan syariat, di sisi lain tetap teguh melaksanakan ajaran tasawuf (Baedowi, Ahmad (ed), 2011:11).

Nilai-nilai Islam yang hidup ini berasal dari sistem pengajaran pesantren yang tidak terikat waktu. Bagi santri belajar di pesantren tidak mengenal adanya batasan waktu, kapan harus mulai dan kapan harus selesai, dan target apa yang harus dicapai. Hal ini sesuai dengan sistem pendidikan pesantren yang menggunakan pendekatan holistic. Pendekatan ini memandang bahwa kegiatan belajar-mengajar di pesantren lebur dalam kehidupan sehari-hari. Idealnya, pengembangan kepribadian yang dituju adalah kepribadian muslim yang kâffah, bukan sekadar muslim biasa (Mastuhu, 1994: 57). Hal ini juga bisa dicapai karena konsep pendidikan pesantren selalu bisa berjalan beriringan dengan perkembangan zaman. Pada zaman dahulu, berdasarkan konsep pendidikannya, pesantren dikenal dalam dua kelompok besar. Pertama pesantren salaf yang tetap mempertahankan pengajaran kitab-kitab Islam klasik sebagai inti pendidikan di pesantren tradisional. Kedua, pesantren modern yang telah memasukkan pelajaran-pelajaran umum dalam madrasahmadrasah yang dikembangkannya, atau membuka tipe-tipe sekolah umum dalam lingkungan pesantren (Dhofier, 1982: 41-42). Kelompok pertama bisa dilihat dari sistem kurikulum yang digunakan Pesantren Tebuireng di awal berdirinya. Pesantren Tebuireng berdiri pada tahun 1899. Pada awal pendiriannya pesantren ini mengajarkan pengetahuan agama Islam dari kitab-kitab klasik menggunakan sistem sorogan dan bandongan sampai tahun 1916 (Dhofier, 1982: 104). Kelompok kedua bisa dilihat dari kemunculan Pesantren Modern Gontor pada tahun 1926.

Selaras dengan perkembangan jaman, tipologi tersebut pun mengalami perubahan. Pada awal abad XXI tipologi pesantren berkembang menjadi lima kelompok besar. (1) pesantren salaf, yaitu pesantren yang di dalamnya terdapat sistem pendidikan salaf (wetonan atau bandongan dan sorogan) dan sistem klasikal, (2) pesantren semiberkembang, yaitu pesantren yang di dalamnya terdapat sistem pendidikan salaf (wetonan atau bandongan dan sorogan) dan sistem madrasah swasta dengan kurikulum $90 \%$ agama dan $10 \%$ umum, (3) 
pesantren berkembang, yaitu pesantren seperti semi-berkembang, hanya saja lebih variatif, yakni $70 \%$ agama dan $30 \%$ umum, (4) pesantren modern, yaitu seperti pesantren berkembang, hanya saja sudah lebih lengkap dengan lembaga pendidikan yang ada di dalamnya sampai perguruan tinggi, dan dilengkapi dengan takhashush bahasa Arab dan Inggris, dan (5) pesantren ideal, yaitu pesantren sebagaimana pesantren modern, hanya saja lembaga pendidikan yang ada lebih lengkap terutama dalam bidang keterampilan yang meliputi teknik, perikanan, pertanian, perbankan, dan lainnya yang benar-benar memerhatikan kualitas dengan tidak menggeser ciri khas pesantren (Nasir, 2005: 87-88).

Dari tipologi tersebut dapat dilihat bagaimana usaha pesantren untuk terus berubah seiring perkembangan jaman. Modernisasi disikapi dengan kebijakan-kebijakan yang tidak melulu berorientasi Barat tetapi lebih kepada sebuah harmonisasi antara agama dan pengetahuan Barat. Hal ini sejalan dengan konsep modernisme yang dikemukakan oleh Fazlur Rahman dan Bassam Tibbi. Menurut Fazlur Rahman, modernisme adalah fenomena keagamaan yang menunjukkan adanya usaha harmonisasi antara agama dan pengaruh modernisasi dan westernisasi yang berlangsung di dunia Islam sedangkan Bassam Tibbi menekankan pada akulturasi budaya yakni integrasi ilmu pengetahuan dan teknologi ke dalam Islam dan menghindari aspek negatif dalam penerapannya (Mahendra, 1999: 13-16).

Modernisasi dan inovasi di dunia pesantren kemudian dititiktekankan pada kurikulum dan sistem pengajarannya. Hal ini sesuai dengan pendapat Mukti Ali yang menyadari ada kelemahan metodologi dalam sistem pendidikan Islam di pesantren. Dia menyebut tiga kelemahan mendasar pendidikan Islam dan menuntut segera dilakukannya pembaruan di dalamnya. Pertama, kelemahan menguasai bahasa asing selain bahasa Arab, terutama bahasa Inggris. Kedua, kelemahan dalam metode penelitian ilmu agama Islam atau metode pemahaman Islam. Ketiga, kelemahan dalam minat ilmu (Shiddiqi, 1993: 599).

Inovasi dan modernisasi yang ditunjukkan pesantrenpesantren adalah usaha mereka bukan hanya untuk bertahan dalam derasnya perkembangan zaman tetapi juga merupakan sebuah 
usaha untuk memperbaiki, meningkatkan, dan mengembangkan sistem pendidikan mereka. Menurut Azra (1999: 34) respons pesantren terhadap inovasi dan modernisasi pendidikan Islam dan perubahan-perubahan sosial ekonomi yang berlangsung dalam masyarakat Indonesia sejak awal abad XXI dapat dipetakan dalam empat komponen, yaitu: pertama, inovasi dan modernisasi atau pembaruan substansi pendidikan pesantren dengan memasukkan subjek umum dan vocational; kedua, pembaruan metodologi, seperti sistem klasikal, penjenjangan; ketiga, pembaruan kelembagaan, seperti kepemimpinan pesantren, diversifikasi lembaga pendidikan; dan keempat, pembaruan fungsi, dari fungsi kependidikan ke fungsi sosial dan ekonomi yang lebih luas. Hal tersebut kemudian dikuatkan oleh pendapat Haidar Putra Daulay yang muncul kemudian. Dia menyatakan bahwa ada tiga aspek dalam modernisasi dan inovasi sebuah pesantren. Pertama, segi metode, yaitu dari metode sorogan dan wetonan ke metode klasikal; kedua, isi materi, yaitu sudah mulai mengadaptasi materi-materi baru selain tetap memertahankan kajian kitab kuning; dan ketiga, manajemen, yaitu dari kepemimpinan tunggal kiai menuju demokratisasi kepemimpinan kolektif (Daulay, 2007: 58-59).

Dalam perkembangan terakhir pesantren mempunyai kecenderungan-kecenderungan baru dalam rangka inovasi terhadap sistem yang selama ini digunakan, yaitu: (1) mulai akrab dengan metodologi modern; (2) semakin berorientasi pada pendidikan yang fungsional, terbuka atas perkembangan di luar dirinya; (3) diversifikasi program dan kegiatan makin terbuka, ketergantungannya dengan kiai tidak absolut, dan dapat membekali santri dengan berbagai pengetahuan di luar mata pelajaran agama maupun keterampilan yang diperlukan di lapangan kerja; dan 4) dapat berfungsi sebagai pusat pengembangan masyarakat. Hal ini mengasumsikan bahwa pada dasarnya pesantren kini telah mengalami transformasi budaya, sistem, dan nilai (Mujib, 2006: 237). Sejalan dengan hal tersebut, pesantren dalam perkembangannya, karena dipengaruhi oleh perkembangan pendidikan dan tuntutan dinamika masyarakat, tidak lagi hanya berkutat pada pendidikan keagamaan saja, namun telah menyelenggarakan pendidikan jalur sekolah formal dan berbagai kegiatan lain yang tidak hanya bersifat keagamaan (Departemen Agama RI, 2005: 3) 
Hal ini mengindikasikan bahwa pesantren sekarang ini membutuhkan sentuhan nilai-nilai yang diusung dan dibawa oleh gerbong modernitas, seperti sentuhan teknologi modern, globalisasi, nilai-nilai pluralisme, multikulturalisme, inklusifisme, dan yang lainnya sebagai dinamika, eksistensi, dan bahkan transformasi yang dilakukan pesantren dalam berbagai bidang demi kehidupan masyarakat luas (As'ary, 1996: 56). Hal inilah yang kemudian menginspirasi berdirinya sebuah pesantren megah di daerah Indramayu Jawa Barat. Pesantren tersebut bernama Ma'had Al-Zaytun.

Para pendiri Ma'had Al-Zaytun menemukan kenyataan tentang adanya perbedaan kualitas yang terlalu jauh antara kaum muslim Indonesia dengan kaum lainnya. Oleh karena itu, diperlukan jalan memintas untuk menutupi jurang perbedaan tersebut. Jalan memintas tersebut adalah perbaikan kualitas pendidikan umat Islam Indonesia. Menurut mereka, kondisi umat Islam Indonesia masih tergolong kaum yang belum mandiri dibandingkan bangsa-bangsa lain. Hal ini dikarenakan kurangnya penguasaan ilmu pengetahuan dan keterampilan yang memadai di kalangan umat Islam Indonesia. Justru mereka melihat bahwa umat Islam Indonesia hanya menonjol dalam sisi kuantitasnya. Bagi mereka, kondisi ini adalah realitas yang tidak bisa dibantah (Majalah Al-Zaytun, 2000: 13).

Sejak awal berdiri Ma'had Al-Zaytun menitikberatkan perjuangannya pada sektor pendidikan. Perkembangan pendidikan di pesantren tersebut berlangsung dengan cepat dan kini mereka menjelma menjadi pusat pendidikan modern yang berusaha mengaplikasikan sebuah sistem pendidikan terintegrasi dengan nama sistem pendidikan satu pipa (one pipe system education). Modernitas pendidikan di Ma'had AL-Zaytun salah satunya dapat dilihat dari pelaksanaan program-program pendidikan yang selalu mengacu pada standar kualifikasi internasional, seperti: program ICDL (International Computer Driving Licence) dan ICCS (International Certificate in Computer Studies). Hal ini sejalan dengan konsep As'ari (1996: 56) tentang inovasi dan modernisasi dalam pesantren yang telah dikemukakan di atas. Di sini Ma'had Al-Zaytun berusaha menjadi gerbong modernitas yang mana membawa sentuhan teknologi modern, globalisasi, nilai-nilai pluralisme, dan kebangsaan serta multikulturalisme. Permasalahan utama yang kemudian 
berusaha dijawab dalam artikel ini adalah apakah modernitas dan inovasi yang dilaksanakan dan berusaha dicapai oleh Ma'had AlZaytun tidak berlawanan bahkan tidak menggusur nilai-nilai utama sebuah pesantren. Sebuah nilai yang berusaha menjadikan Islam sebagai pedoman/jalan hidup atau dengan kata lain berusaha menjadikan manusia menjadi muslim yang kaffah.

\section{B. Pembahasan}

Ma'had Al-Zaytun adalah sebuah pesantren. Pemilihan pesantren sebagai salah satu usaha dari Yayasan Pesantren Indonesia (YPI) berdasarkan pertimbangan bahwa pesantren- di Malaysia disebut Ma'had- merupakan lembaga pendidikan asli Indonesia. Hal ini bisa dilihat dari pidato AS Panji Gumilang dalam peresmian Ma'had Al-Zaytun.

Mengapa pendidikan yang ditempuh berbentuk pesantren? Menurut pemahaman kami, kehidupan pesantren merupakan lembaga kehidupan masyarakat yang dapat mewujudkan kebersamaan, keterbukaan, kebebasan, tolong-menolong, saling hormat menghormati, yang selalu haus akan ilmu pengetahuan dan beriwa mandiri. Sebab kehidupan pesantren selalu mencontoh dan dicontohi oleh kehidupan para pembimbing dan kiai dengan contoh yang baik yang tak henti- hentinya sehingga akan menimbulkan suatu kebiasaan positif yang tak henti-hentinya dilaksanakan di perkampungan tersebut (Majalah Al-Zaytun, 2000: 54-55).

Pesantren di daerah Indramayu, Jawa Barat ini berdiri di atas lahan seluas 1200 hektar. Oleh karena itulah, Washington Times (29 Agustus 2005) menyebutnya sebagai pesantren terbesar se-Asia Tenggara (the largest Islamic madrasah in Southeast Asia) (Crouch, 2014: 86). Dengan lahan yang begitu luas Ma' had Al-Zaytun memiliki keleluasaan untuk membangun dan mengembangkan pesantren mereka. Pembangunan fisik di Ma'had Al-Zaytun mulai dirintis pada tahun 1995 dan pada tahun 1998 berhasil mendirikan dua gedung pendidikan, yakni gedung Abu Bakar as-Shiddiq, Umar bin Khattab dan satu unit asrama Al-Musthafa. Bersamaan dengan pembangunan fisik, mereka membentuk koordinator wilayah (korwil) yang disebar ke berbagai daerah yang bertugas mensosialisasikan keberadaan Ma'had Al-Zaytun sekaligus merekrut calon siswa. Koordinator- 
koordinator ini membentuk ketua, wakil ketua, sekretaris dan bendahara (Majalah AL-Zaytun edisi 10/2000: 48).

Pembangunan besar-besaran ini kemudian dibuktikan dengan telah berdirinya enam gedung pembelajaran megah, yaitu: gedung Abu Bakar Al-Shiddiq, Gedung Umar Ibnu Khaththab, Gedung Utsman Ibnu Affan, Gedung Ali bin Abi Thalib, gedung Ir. Soekarno dan gedung HM Soeharto. Gedung pembelajaran ini ditopang oleh gedung-gedung asrama yang juga megah, yaitu: Gedung Al-Mushthofa, Gedung Al-Fajr, Gedung Al-Nur, Gedung AlMadani, Gedung Persahabatan, dan Gedung Syarifah Hidayatullah. Sebagai sistem pendidikan ala pondok pesantren, Ma'had Al-Zaytun memang memiliki asrama-asrama bagi para siswa yang terletak di sebelah utara gedung pembelajaran. Gedung-gedung asrama ini setiap unitnya menempati lahan seluas 22.000 meter persegi yang dapat menampung sekurang-kurangnya 1700 santri dengan kapasitas setiap kamar dihuni 10 orang. Tiap unit bangunan asrama dibuat dalam enam blok. Masing-masing blok menghadap ke arah luar dengan jarak pandang yang terbuka bebas ke luar. Di setiap lantai asrama terdapat hall besar di tengah-tengah gedung yang berukuran 30x32 m. Hall ini berfungsi sebagai wahana komunikasi antarsantri dengan berbagai ragam budaya dari berbagai suku bangsa (Baedowi, 2011: 162).

Awal pembelajaran di Ma'had Al-Zaytun dimulai pada 1 Juli 1999. Pada pembelajaran pertama tersebut Ma'had menerima siswa-siswi berjumlah 1584 orang. Tenaga pengajar dan murabbi yang diterima sebanyak 296 orang terdiri dari murabbi sebanyak 159 orang dan mudarris sebanyak 137 orang. Mudarris adalah guru yang diberi tugas mengajar mata pelajaran tertentu dan mengajar di kelas. Murabbi adalah pembimbing yang bertugas memberikan pendampingan terhadap santri di luar kelas. Murabbi membimbing santri baik dalam belajar, mengikuti kegiatan ekstrakurikuler atau bimbingan lainnya yang diperlukan santri. Seorang mudarris berperan juga sebagai murabbi tetapi tidak semua murabbi bertindak sebagai mudarris (Tolkhah, Imam dan Choirul Fuad Yusuf, 2002: 37). Setelah diseleksi siswa-siswa yang diterima berjumlah 1459 orang. Pada tahun yang sama, tepatnya 27 Agustus 1999, Presiden BJ Habibie pun meresmikan Ma’had ini (Majalah Al-Zaytun, 2000: 8-15). 
Kesuksesan menarik para santri di awal berdirinya tidak lepas dari visi misi Ma'had Al-Zaytun. Visi misi tersebut tersimpul dalam moto: Al-Zaytun Pusat Pendidikan Pengembangan Budaya Toleransi dan Perdamaian yang didalamnya mengandung arti perbaikan kualitas pendidikan ummat yang berorientasi pada penanaman dan habitualisasi nilai-nilai perdamaian dan toleransi. Selain itu, Ma'had Al-Zaytun juga memiliki moto: Pesantren Spirit but Modern System yang diartikan bahwa Ma'had Al-Zaytun adalah sebuah lembaga pendidikan yang mempunyai semangat sebuah pesantren dan menggunakan sistem modern. Lembaga pesantren ini akan dihuni oleh para individu santri yang berakhlaq mulia, berpengalaman luas, berpikiran bebas dan berbadan sehat (Majalah Al-Zaytun Edisi $15 / 2001)$.

Visi misi tersebut kemudian mewujud dalam sebuah sistem pendidikan modern yang dicanangkan oleh A.S. Panji Gumilang. Menurutnya pendidikan modern bermakna; 1) visioner, berarti visi pendidikan mesti diarahkan kepada kebangkitan Indonesia yang dapat berdiri sama tinggi duduk sama rendah di tataran antarbangsa, 2) berprogram jelas, program pendidikan harus diarahkan kepada kebangkitan bangsa Indonesia menjadi setara dengan bangsa-bangsa lain dalam segala bidang dan aspek kemajuan, 3) berorientasi ilmu pengetahuan, 4) berdisiplin, dan 5) beretos kerja, tanda masyarakat modern adalah mempunyai etos kerja tinggi dan bertanggung jawab terhadap pekerjaannya (Simanullang, 2015: 308). Kelima hal tersebut menunjukkan sebuah nilai-nilai Islami yang selaras dengan termaterma modern sehingga semua pemangku kepentingan khususnya di bidang pendidikan Ma'had Al-Zaytun akan dengan mudah memahami dan melaksanakannya.

Selain visi-misi pendidikan modern, Ma'had Al-Zaytun juga mempunyai arah dan tujuan pendidikan yang jelas, yaitu: mempersiapkan peserta didik untuk berakidah kokoh terhadap Allah dan syariat-Nya, menyatu di dalam tauhid, berakhlaqul karimah, berilmu pengetahuan yang luas, dan berketerampilan yang tinggi yang kesemuanya itu terkandung dalam kata basthotan fil 'ilmi wal jismi. Menurut AS Panji Gumilang kata tersebut tercermin dalam pribadi bangsa yang cerdas (intelektual, emosional, spritual), bangsa yang bajik dan bijak, mampu memposisikan diri dalam berbagai 
kondisi yang tersimpul dalam berbagai sikap. Selain itu, Ma'had AlZaytun juga berusaha mengembangkan, mengimplementasikan, dan membudayakan nilai-nilai kebangsaan, perdamaian dan toleransi. Hal tersebut terlihat ketika A.S. Panji Gumilang selalu mengajak umat beragama memaknai (belajar dari sejarah) dengan kembali kepada fitrah beragama, yaitu toleransi yang harus ditegakkan sebagai keyakinan pokok (akidah) dalam beragama (Simanullang, 2015: 73).

Untuk mencapai arah dan tujuan tersebut Ma'had Al-Zaytun menggunakan kurikulum yang mengacu kepada Kementerian Agama dan Kementerian Pendidikan dan Kebudayaan. Kurikulum tersebut berbentuk kurikulum pendidikan Islam yang secara komprehensif dan modern selalu sensitif dan tanggap terhadap perkembangan zaman, selalu up to date ('ashry). Spesifikasi dan ciri khasnya adalah penguasaan Al-Qur'an secara mendalam, terampil berkomunikasi menggunakan bahasa-bahasa antarbangsa yang dominan, berpendekatan ilmu pengetahuan, berketerampilan teknologi dan fisik, berjiwa mandiri, penuh perhatian terhadap aspek dinamika kelompok dan bangsa, berdisiplin tinggi serta berkesenian yang memadai (Simanullang, 2015: 327).

Kurikulum Al-Zaytun juga menganut falsafah flexible dan integrated curriculum (kurikulum yang fleksibel dan terintegrasi). Terintegarsi bermakna mengadopsi keseluruhan kurikulum pendidikan nasional (Diknas) dan kurikulum Departemen Agama dan ditambah dengan kurikulum muatan lokal, seperti: tahfidh Qur'an, pendalaman bahasa, pembahasan Kitab Kuning, jurnalistik, pengembangan budaya perdamaian dan toleransi serta metode didaktik yang mengajarkan siswa untuk dapat mengajar nantinya. Ketiga kurikulum yang terintegrasi tersebut diterapkan secara bertahap disesuaikan waktu dan visi misi yang telah dicanangkan semenjak awal. Kurikulum fleksibel bermakna bahwa kurikulum yang diterapkan selalu menerima koreksi dan perubahan-perubahan sesuai dengan target yang ingin dicapai. Evaluasi dilakukan oleh Badan Litbang Al-Zaytun setahun sekali melalui sidang. Salah satu contoh keputusan yang dihasilkan sidang Litbang adalah adanya kursus komputer yang diselenggarakan Al-Zaytun Global Information and Communication Technology (AGICT) dan Program Tabungan 
Bahasa, Tahfidz Quran, Perilaku disiplin di Masjid, dan rihlah ilmiah ke lembaga-lembaga negara. Kesemuanya adalah hasil Litbang pada tanggal 13 Juni 2003. Sidang Litbang merupakan usaha Ma'had AlZaytun untuk selalu melakukan pembaharuan sistem manajemen mereka. Sidang ini dilakukan setiap tahun sekali yang diberi nama sidang Litbang Ma'had Al-Zaytun. Sidang ini diikuti perwakilan setiap unit yang ada di Ma'had Al-Zaytun. Segala persoalan seperti kelemahan pelaksanaan program di setiap unit penunjang pendidikan dievaluasi pada sidang ini. Dalam pelaksanaannya sidang dipimpin oleh Syekh Ma' had AS Panji Gumilang.

Visi-misi pendidikan modern, arah dan tujuan pendidikan yang jelas serta kurikulum yang setiap tahun dilakukan evaluasi tersebut kemudian memunculkan sebuah sistem pendidikan yang tidak terputus dalam pelaksanaan pendidikan formalnya yang kemudian dikenal dengan Sistem Pendidikan Satu Pipa (One Pipe System Education). Sistem tersebut diwujudkan dalam pelaksanaan pendidikan dari kelas satu hingga kelas dua puluh. 20 kelas tersebut terbagi dalam lima tingkatan. Pertama, tingkat dasar (elementary). Dari tahun pertama hingga tahun keenam, umur 6-12 tahun. Kedua, tingkat menengah (secondary and senior high school). Dari tahun ketujuh sampai tahun ke-12, umur 13-18 tahun. Ketiga, tingkat sarjana (Strata-1), tahun ke-13 sampai tahun ke-15, umur 19-21 tahun. Keempat, tingkat magister (Strata-2), tahun ke-16 sampai tahun ke17, umur 21-23 tahun. Kelima, tingkat doktoral (Strata-3), tahun ke18 sampai tahun ke-20, umur 24-26 tahun. Jenjang pendidikan dari sistem ini antara lain; 1) Al-Ibtida'i, 2) Al-'I'dadi, 3) Al-Tsanawi, 4) Al-Wustho, 5) Al-Ali, 6) Al-Jami'ah. Bagi tingkat Tsanawi yang tidak mampu (dikarenakan keterbatasan kemampuan dan lain sebagainya) untuk mencapai tingkat Wustho, mereka diberi arahan untuk memilih vocational, keterampilan, atau kejuruan. Sementara itu, untuk jenjang Al-Jami'ah penyelenggaraanya berdasarkan prestasi selektif.

Untuk menyukseskan Sistem Pendidikan Satu Pipa tersebut, Ma'had Al-Zaytun kemudian menerapkan pembelajaran yang bukan hanya secara every day tetapi secara every hour. Every hour diartikan sebagai budaya berlomba-lomba dalam kebaikan sepanjang waktu. Budaya Islam terlihat di Ma'had Al-Zaytun dalam penerapan nilainilai dan etika islami yang dibalut budaya modern. Hal ini salah 
satunya mewujud dalam etika sosial di lingkungan Ma'had Al-Zaytun, seperti pemakaian simbol-simbol Islam; ucapan salam kala bertemu, dan panggilan abi, ummi, akhi dan ukhti. Dalam rangka semangat penerapan hidup islami nama-nama santri kemudian diganti atau dilengkapi dengan nama yang dianggap lebih islami, seperti; Abu Salam, Abu Jihad, atau Syekh Ma'had Al-Zaytun (Baedowi, 2011: 178).

Selain itu, sesuai teknis sistem pendidikan nasional siswa setingkat SLTA di Ma'had Al-Zaytun juga dilakukan penjurusan sesuai dengan bakat dan minat mereka. Penjurusan tersebut dilakukan secara khusus oleh tim penyeleksi. Hal-hal yang menjadi pertimbangan adalah; nilai akademis, minat, hasil penelitian tim seleksi tentang nilai akademis dan minat santri serta hasil penelitian tim yang dikonsultasikan kepada orang tua santri. Termasuk di dalamnya hasil tes IQyang diujikan kepada santri oleh tim psikolog Al-Zaytun. Penjurusan dimulai secara bertahap dari kelas 10 dan 11 atau setara dengan kelas 1 di tingkat SMU atau Madrasah Aliyah. Penjurusan tersebut disesuaikan dengan perkembangan kurikulum nasional.

Selain sistem penjurusan, sistem pendidikan ini juga menggunakan pengklasifikasian santri atas lima grade berdasarkan nilai akademis yang diperolehnya, yaitu: Kelas Khusus (kelas B) dengan nilai rata-rata lebih besar atau sama dengan 9; Kelas Baik (kelas C) dengan nilai rata-rata 8 hingga 8,99; Kelas Sedang (Kelas D) dengan nilai rata-rata 7 hingga 7,99; Kelas Cukup (Kelas E) dengan nilai rata-rata 6 hingga 6,99 dan Kelas Kurang (Kelas F) dengan nilai lebih kecil atau sama dengan 6 (kini kelas F telah ditiadakan dan menganut sistem tinggal kelas/ tidak naik kelas). Pengklasifikasian ini merupakan bagian dari upaya untuk meningkatkan kualitas akademik para santri dan menumbuhkan sikap kompetisi di dalam diri santri. Penglasifikasian ini juga berpengaruh pada penempatan kamar di asrama dengan tetap memperhatikan keberagaman asal daerah. Hal ini dilakukan untuk memudahkan pembinaan akademis pada saat belajar di kamar yang dilakukan pada pukul 20.00-22.00. Dalam prosesnya siswa kelas tinggi terlibat secara langsung dalam aktivitas manajemen asrama dan siswa kelas tertinggi dipilih menjadi wali kamar bagi kamar-kamar yang dihuni oleh santri kelas I dan kelas II. Penempatan santri di setiap kamar asrama berdasarkan tingkatan 
kelas. Artinya, kelas I tinggal sekamar dengan kelas I (Baedowi, 2011: 163).

Peningkatan akademik juga bukan hanya mengarah kepada santri semata. Akan tetapi, hal itu juga berlaku untuk para mudarris dan murabbi. Setiap mudarris dan murabbi dibina dan dikembangkan dengan terus menerus, ditingkatkan kapasitas keilmuannya dengan mengikuti studi lanjut $\mathrm{S} 1$ bagi yang belum sarjana, dan $\mathrm{S} 2$ bagi lulusan S1. Peningkatan kualitas keilmuan para mudarris dan murabbi juga dilakukan melalui pendidikan nonformal di Ma'had Al-Zaytun ketika libur. Untuk kepentingan studi lanjut bagi mudarris dan murabbi, Ma'had Al-Zaytun melakukan kerjasama dengan berbagai perguruan tinggi (Baedowi, 2011:168-169). Selain itu, Ma'had Al-Zaytun juga berusaha menyamakan visi dan misi mereka dalam hal pendidikan khususnya tentang toleransi dan perdamaian kepada guru-guru yang mengajar di sana. Hal ini terlihat ketika pembelajaran tahun ajaran 2000-2001, sebelum bertugas mengajar, guru-guru harus mengikuti penataran guru lebih dahulu yang disebut irsyad kurikulum. Program ini dilakukan selama sebulan penuh yang mana berisi penyamaan visi dan misi dengan beberapa materi. Salah satu materi berhubungan dengan toleransi dan perdamaian, yaitu materi Piagam Madinah dan Declaration of Human Right PBB (Ausop, 2011: 327). Tujuan pemberian materi tersebut adalah agar calon guru memahami benar tentang esensi dan alasan Ma'had Al-Zaytun memilih motto sebagai pusat toleransi dan perdamaian.

Sistem Pendidikan Satu Pipa mulai dilaksanakan di Ma'had Al-Zaytun pada tahun 2005, dan sejak tahun ajaran 2009-2010 ada sebuah perubahan yang signifikan di dalamnya, salah satunya adalah pelajar kelas XII mengimplementasikan sistem koedukasi. Artinya penggabungan pelajar laki-laki dan perempuan dalam satu kelas. Juga jumlah hari pembelajaran di dalam kelas perpekan bagi pelajar kelas 1 s.d. XII dilaksanakan selama lima hari yaitu mulai hari Senin sampai Jum'at. Pada hari Sabtu dan Ahad seluruh pelajar wajib mengikuti berbagai kegiatan yang dilakukan di luar jam pelajaran reguler, baik kegiatan wajib maupun kegiatan pilihan sesuai bakat dan minat.

Kegiatan pembelajaran di luar kelas yang wajib diikuti seluruh pelajar di Ma'had Al-Zaytun adalah Muhadlarah, kebahasaan dan kepanduan. Bahasa internasional seperti Inggris, Arab, Mandarin 
diajarkan dengan dukungan laboratorium-laboratorium bahasa dan sistem pengajaran bahasa. Siswa dengan pola pikir global, berbahasa internasional dan berkemampuan skala dunia merupakan bekal yang terus dipersiapkan untuk membentuk pribadi siswa yang utuh. Hal inilah yang kemudian memunculkan sebuah kekhasan pada pesantren ini. Kekhasan yang terletak pada aktivitas santrinya yang ditujukan untuk pembinaan watak pribadi yang mandiri serta diarahkan untuk mengembangkan budaya perdamaian dan toleransi (Harian Pelita, 1999). Pengembangan budaya perdamaian dan toleransi dapat dilihat dalam struktur kurikulum mata pelajaran di MA AlZaytun yang mana semenjak remaja mereka sudah belajar tentang perbedaan dengan dipelajarinya kitab Bidayatul Mujtahid pada kelas XII. Kitab karya Ibnu Rusyd tersebut adalah sebuah kitab fiqih yang membahas tentang fiqih perbandingan madzhab. Hal ini menunjukan bahwa santri Ma'had Al-Zaytun sudah terbiasa dengan perbedaan (khilafyah) masalah fiqih. Suatu perbedaan yang akhir-akhir sering memunculkan konflik pada sesama umat Islam.

Tujuan akhir dari pengimplementasian sistem pendidikan satu pipa di Ma'had Al-Zaytun adalah para santri akan dapat menyelesaikan pendidikan formal sampai tingkat yang paling tinggi pada usia produktif atau usia emas mereka. Selanjutnya mereka akan dapat mengabdikan keilmuannya tersebut kepada nusa, bangsa, serta umat manusia pada umumnya sepanjang hayat mereka.

\section{Simpulan}

Dengan adanya inovasi dan modernisasi, gejala dan kecenderungan beberapa pesantren untuk dapat terbuka pada keilmuan dan isu-isu modern semakin muncul. Indikator yang dapat dilihat salah satunya adalah dengan mulai masuk dan familiarnya pesantren dengan bahasa asing, seperti bahasa Inggris. Hal ini diimbangi dengan penekanan bahasa Arab yang tidak lagi hanya pada penelaahan gramatikanya saja, melainkan bagaimana menguasai bahasa Arab itu sendiri, baik secara lisan maupun teks. Selain itu, bermunculan pula pesantren yang melakukan integrasi keilmuan dan metodologi antara ilmu-ilmu umum dan ilmu-ilmu Islam yang selama ini dianggap tidak dapat dikompromikan atau terjadi dikotomi antara keduanya. Semua hal itu dapat kita temukan dalam sistem pendidikan satu pipa yang dilaksanakan di Ma'had Al-Zaytun. 
Sistem pendidikan satu pipa yang dilaksanakan di Ma'had Al-Zaytun selain secara konsisten berhasil melakukan inovasi dan modernisasi juga tidak melupakan posisi mereka sebagai pesantren yang berfungsi sebagai pusat pendidikan Islam. Hal tersebut diartikan bahwa santri secara penuh berada pada lingkungan pesantren yang mana di dalamnya mereka menganggap kehidupan secara keseluruhan adalah ibadah dengan sistem modern dan merupakan tempat untuk menanamkan nilai-nilai perdamaian dan toleransi. Pandangan ini menurut Abdurahman Wahid merupakan nilai pertama dari tiga nilai utama yang berkembang di pesantren. Nilai ini kemudian dikenal dengan nilai teosentris. Menurut Wahid (2007: 130-132) semenjak pertama kali memasuki kehidupan pesantren, seorang santri sudah diperkenalkan pada sebuah dunia tersendiri, di mana peribadatan menempati kedudukan tertinggi. Dari pemeliharaan cara-cara beribadah ritual yang dilakukan secermat mungkin hingga pada penentuan jalan hidup yang akan dipilih seorang santri sekeluarnya dari pesantren nanti, titik pusat kehidupan diletakkan pada ukuran kehidupan itu sendiri sebagai peribadatan. Ilmu-ilmu agamalah, sebagaimana dimengerti di lingkungan pesantren, yang merupakan landasan pembenaran pandangan sarwa ibadah tersebut.

Nilai-nilai utama sebuah pesantren lainnya yang masih bertahan di Ma'had Al-Zaytun adalah berusaha membentuk pribadi santri yang mandiri dan bersahaja. Nilai tersebut kemudian berpadu dengan pengembangan nilai/prinsip manajemen modern, seperti bersikap berdasarkan ilmu pengetahuan, berorientasi pada program, mengikuti prosedur dalam organisasi, mempunyai etos kerja dan disiplin yang tinggi. Hasil akhir dari prinsip tersebut adalah keikhlasan atau ketulusan bekerja untuk tujuan bersama, tidak memandang suku, agama ataupun ras. Nilai keikhlasan dan ketulusan bekerjasama inilah yang menjadi nilai utama kedua dalam pesantren. Menurut Wahid (2007: 134) menjalankan semua yang diperintahkan kiai dengan tidak ada rasa berat sedikitpun, bahkan dengan penuh kerelaan, adalah bukti nyata sifat keikhlasan dan ketulusan. Hidup pribadi kiai dan santrinya, dilihat dari satu segi, larut sepenuhnya dalam irama kehidupan pesantren yang dipimpinnya, tujuan dan pamrih lain menjadi soal sekunder dalam pandangannya. Secara bersamaan nilai-nilai utama di atas itulah yang membentuk sebuah sistem nilai 
umum, yang mampu menopang berkembangnya karakter mandiri di pesantren.

Nilai-nilai luhur pesantren lain yang berusaha diwujudkan oleh Ma'had Al-Zaytun adalah kecintaan terhadap ilmu khususnya ilmu agama. Nilai utama terakhir ini menurut Wahid (2007: 132133) muncul dari kesatuan antara ilmu dan ibadah yang mana dengan sendirinya akan memunculkan kecintaan mendalam pada ilmu-ilmu agama. Kecintaan ini dimanifestasikan dalam berbagai bentuk, seperti penghormatan santri yang sangat dalam kepada ahli-ahli ilmu agama, kesediaan berkorban dan bekerja keras untuk menguasai ilmu-ilmu tersebut. Kecintaan itu pula yang akan mendorong santri mencari pola-pola kerja tersendiri sepulang dari pesantren. Di Ma'had AlZaytun kecintaan terhadap ilmu kemudian hadir melalui sebuah sistem pendidikan formal yang bernama sistem pendidikan satu pipa. Sistem pendidikan ini terbukti bukan hanya membawa santri lebih bisa bersikap modern dan menjadi intelektual mumpuni tetapi juga tertanamnya nilai-nilai kebangsaan, perdamaian dan toleransi sehingga bisa mewujudkan tujuan utama sebuah pesantren, yaitu menciptakan seorang muslim yang kaffah. 


\section{DAFTAR PUSTAKA}

As’ary, Zubaidi Habibullah. 1996. Moralitas Pendidikan Pesantren. Yogyakarta: Kurnia Kalam Semesta.

Ausop, Asep Zaenal. 2011. Ajaran dan Gerakan NII Kartosowirjo, NII KW IX dan Ma'had Al-Zaytun. Bandung: Tafakur.

Azra, Azyumardi. 1999. Pendidikan Islam: Tradisi dan Modernisasi Menuju Milenium Baru. Jakarta: Logos.

Baedowi, Ahmad (ed). 2011. Al-Zaytun The Untold Stories. Investigasi terhadap Pesantren Paling Kontroversial di Indonesia. Jakarta: Pustaka Alvabet.

Buchori, Mochtar. 1989. Pendidikan Islam di Indonesia: Problema Masa Kini dan Perspektif Masa Depan dalam Islam Indonesia Menatap Masa Depan. Muntaha Azhari dan Abdul Mun'im Saleh (eds). Jakarta: P3M.

Crouch, Mellisa. 2014. Law and Religion in Indonesia: Conflict and the Courts in West Java. Routledge: London and New York

Daulay, Haidar Putra. 2007. Sejarah Pertumbuhan dan Pembaruan Pendidikan Islam di Indonesia. Jakarta: Prenada Media.

Departemen Agama RI. 2005. Pola Pengembangan Pondok Pesantren. Jakarta: Direktorat Jendral Kelembagaan Agama Islam dan Direktorat Pendidikan Keagamaan dan Pondok Pesantren.

Dhofier, Zamahsyari. 1982. Tradisi Pesantren. Jakarta: LP3ES.

Mahendra, Yusril Ihza. 1999. Modernisme dan Fundamentalisme dalam Politik Islam. Jakarta: Paramadina.

Mastuhu. 1994. Dinamika Sistem Pendidikan Pesantren. Jakarta: INIS.

Mujib, Abdul dan Jusuf Mudzakkir. 2006. Imu Pendidikan Islam. Jakarta: Kencana Prenada Media.

Nasir, M. Ridwan. 2005 Mencari Tipologi Format Pendidikan Ideal: Pondok Pesantren di Tengah Arus Perubahan. Yogyakarta: Pustaka Pelajar.

Shiddiqi, Norouzzaman. 1993. Metode Ilmu Agama Islam atau Metode Pemahaman Agama Islam Menurut Prof. Dr. H.A. 
Mukti Ali dalam Agama dan Masyarakat: 70 Tahun H.A. Mukti Ali. Abdurrahman (eds). Yogyakarta: IAIN Sunan Kalijaga Press.

Simanullang, Robin. 2015. Al-Zaytun: Sumber Inspirasi Bermasyarakat, Berbangsa dan Bernegara. Jakarta: Pustaka Tokoh Indonesia.

Tolkhah, Imam dan Choirul Fuad. 2002. Ma'had Al-Zaytun di Indramayu. Jakarta: Badan Litbang Agama dan Diklat Keagamaan.

Wahid, Abdurahman. 2007. Menggerakkan Tradisi: Esai-esai Pesantren. Yogyakarta: LKIS. 